\title{
Helium isotope geochemistry of mantle xenoliths and Cenozoic basalts in Jeju Island, South Korea
}

Donghwan Kim ${ }^{1}$, Hyunwoo Lee ${ }^{1}$, Jonguk Kim², Jihye $\mathrm{Oh}^{2}$, Finlay M. Stuart ${ }^{3}$

${ }^{1}$ Seoul National University, Seoul 08826, Republic of Korea (correspondence: ehdghks1126@snu.ac.kr)

${ }^{2}$ Korea Institute of Ocean Science and Technology, Busan 49111, Republic of Korea

${ }^{3}$ Scottish Universities Environmental Research Centre, Glasgow, UK

Jeju Island (South Korea) is an intraplate volcano located at the eastern margin of the Eurasian plate, which has begun volcanic activity $2 \mathrm{Ma}$ ago. Although there have been a lot of geochemical studies on Jeju Island, it is still controversial whether the source of magma is upper mantle or mantle plume $[1,2]$. Here we first report helium isotope compositions $\left({ }^{3} \mathrm{He} /{ }^{4} \mathrm{He}\right)$ in mantle xenoliths and basalts from Jeju Island in order to constrain the source of magma. Major element geochemistry of whole-rocks and minerals analyzed by XRF and EPMA, respectively. ${ }^{3} \mathrm{He} /{ }^{4} \mathrm{He}$ ratios of $\mathrm{Ol}$ and $\mathrm{Cpx}$ separates were measured by a noble gas mass spectrometer. The mantle xenoliths from SE Jeju are spinel lherzolite with ${ }^{3} \mathrm{He} /{ }^{4} \mathrm{He}$ ratios of $\mathrm{Ol}$ ranging from 2.9 to $6.5 \mathrm{R}_{\mathrm{A}}$. These ratios are generally comparable with ${ }^{3} \mathrm{He} /{ }^{4} \mathrm{He}$ ratios of the Korean peninsula $\left(3.5-7.9 \mathrm{R}_{\mathrm{A}}\right)$ and the European mantle xenoliths $\left(5.2-7 \mathrm{R}_{\mathrm{A}}\right)[3,4]$. The basalts from the west Jeju Island are tholeiitic to alkaline, showing ${ }^{3} \mathrm{He} /{ }^{4} \mathrm{He}$ ratios of $\mathrm{Ol}$ and $\mathrm{Cpx}$ phenocrysts from 3.5 to $7.3 \mathrm{R}_{\mathrm{A}}$, similar to the Jeju mantle xenolith values. It is unlikely that ${ }^{3} \mathrm{He} /{ }^{4} \mathrm{He}$ ratios of the basalts indicate crustal contamination by using the relationship of $\mathrm{SiO}_{2}$ and $\mathrm{K}_{2} \mathrm{O} / \mathrm{P}_{2} \mathrm{O}_{5}$. Thus, the ${ }^{3} \mathrm{He} /{ }^{4} \mathrm{He}$ ratios of the basalts can provide information on the source of magma. According to the seismic tomography model in Jeju Island, decompression melt could occur at the sub-lithospheric mantle depth by edge-driven mantle convection [5]. Moreover, based on trace element modeling [6], it has been suggested that the mantle source of Jeju basalt is mostly garnet lherzolite and eclogite. Therefore, we suggest that the lower part of SCLM played a pivotal role in the production of magma in Jeju Island.

[1] Choi et al. 2006. Chem. Geol. 221:40-64. [2] Tatsumi et al. 2005. J. Petrol. 46:523-553. [3] Gautheron and Moreira. 2002.

Earth Planet. Sci. Lett. 199:39-47. [4] Kim et al. 2005. Geochem. J. 39:341-356. [5] Song et al. 2018. J. Geophys. Res. Solid Earth. 123:6784-6801. [6] Kim et al. 2019. Lithos. 326-327:476-490. 